Energy Research Journal 2 (1): 1-5, 2011

ISSN 1949-0151

C 2011 Science Publications

\title{
Effect of Fuel Properties on Exhaust Emissions during Warm-Up Process
}

\author{
${ }^{1}$ Rosli Abu Bakar and ${ }^{2}$ Beny Cahyono \\ ${ }^{1}$ Department of Mechanical Engineering, \\ University Malaysia Pahang, Pahang, Malaysia \\ ${ }^{2}$ Department of Marine Engineering, \\ Sepuluh Nopember Institute Technology of Surabaya, Surabaya, Indonesia
}

\begin{abstract}
Problem statement: Increasing air pollutions the big problem form internal combustion engines. Several attempts have been done to get a cleaner combustion process, one of which is the use of fuel ethanol in gasoline engines. Approach: The addition of ethanol in fuel will be change fuel properties. Results: To know the effect of fuel properties on engine performance and emissions produced, in this study was conducted tests against some root material, which is 95 octane gasoline, ethanol/gasoline 10, 20\% ethanol, ethanol 30\%, when the warm-up process. Conclusion/Recommendations: Result from this research, addition of ethanol in the fuel produces emissions of $\mathrm{HC}$ and $\mathrm{CO}$ is higher at the start, but with increasing time engine running the addition of ethanol to reduce emissions.
\end{abstract}

Key words: Fuel properties, exhaust emission, gasoline engine, gas chromatography

\section{INTRODUCTION}

Automotive development as a means of transportation, so enable people in performing a job. Beside simplify the activity, the use of vehicles also cause a very bad impact on the environment, particularly flue gas from burning fuel that does not decompose or be burned perfectly. As known that the fuel combustion process of internal combustion engines produce exhaust gases containing $\mathrm{CO}, \mathrm{NO}_{2}, \mathrm{HC}, \mathrm{C}, \mathrm{H}_{2}$, $\mathrm{CO}_{2}, \mathrm{H}_{2} \mathrm{O}$ and $\mathrm{N}_{2}$, where many environment polluting. Elemental Carbon Monoxide (CO) which affect the health of living things deserve special study, because the elements of carbon monoxide from burning toxic to human blood during respiration, as a result of reduced oxygen in the blood tissue. Amount of $\mathrm{CO}$ present in the blood, the duration of inhaled and respiratory rate determines the amount carboksihemoglobin (combination of hemoglobin/carbon-monoxide) in the blood and if the amount of $\mathrm{CO}$ has already reached a certain amount/saturation in the body, it will cause death.

In addition to $\mathrm{CO}$ gas, some gas from burning a very disturbing health of $\mathrm{NO}_{\mathrm{x}}, \mathrm{HC}, \mathrm{CO} . \mathrm{NO}_{\mathrm{x}}$ gases can cause shortness of breath in patients with asthma, often because difficulty sleeping cough and also cause fog. $\mathrm{NO}_{\mathrm{x}}$ is a gas that is colorless and odorless, has no taste and quick to react with the $\mathrm{O}_{2}$ and turn into $\mathrm{NO}_{2} . \mathrm{NO}_{2}$
Gas (nitrogen dioxide), can also damage lung tissue and if the joint $\mathrm{H}_{2} \mathrm{O}$ will form a nitric acid $\left(\mathrm{HNO}_{3}\right)$, which in turn can cause acid rain which is very harmful to the environment. NOx gas is formed due to high temperatures. Hydrocarbon (HC) is a less harmful gas for human life, but of a mixture of the cause of the haze of smoke (Smog). Emission of hydrocarbons contained in exhaust gas in the form of unburned petroleum. Hydrocarbons contained in the evaporation process of fuel in the tank, carburetor and gas leakage through the gap between the cylinder and the piston goes into the crank shaft which is called blow by gases.

In the combustion process is needed oxygen. The experts have identified that consists of air, Oxygen $\left(\mathrm{O}_{2}\right)$ as much as $21 \%$, Nitrogen $\left(\mathrm{N}_{2}\right) 78$ and $1 \%$ other gases. Theoretical perfect combustion ratio is obtained with air/fuel (Air to fuel ratio) is 14.7 and is often referred to as the stoichiometry and often referred to also as the ratio of Lambda $=1$. Air to Fuel Ratio (often abbreviated AFR)> 14.7 referred to as Lean Combustion whereas otherwise known as Rich combustion.

In an ideal combustion process will produce $\mathrm{H}_{2} \mathrm{O}$, $\mathrm{CO}_{2}$ and $\mathrm{N}_{2}$, but in practical combustion in the engine is not perfect even in machines with high Technology. In the above diagram can be seen, the black line is the line where the combustion stoichiometry is more or less value will be obtained and be the emission standard. 
Energy Rec. J. 2 (1): 1-5, 2011

Table 1: Fuel properties

\begin{tabular}{|c|c|c|c|c|c|}
\hline \multirow[b]{2}{*}{ Property item } & \multicolumn{4}{|l|}{ Test fuel } & \multirow[b]{2}{*}{ Method } \\
\hline & E 0 & E10 & E20 & E30 & \\
\hline Density $\left(\mathrm{kg} \mathrm{L}^{-1}\right.$ at $\left.15.5^{\circ} \mathrm{C}\right)$ & 0.7575 & 0.7608 & 0.7645 & 0.7682 & ASTM D 4052 \\
\hline Ron (octane number) & 95.4000 & 98.1000 & 100.7000 & 102.4000 & ASTM D 2699 \\
\hline $\mathrm{RVP}\left(\mathrm{kPa}\right.$ at $\left.37.8^{\circ} \mathrm{C}\right)$ & 53.7000 & 59.6000 & 58.3000 & 56.8000 & ASTM D 5191 \\
\hline Sulfur (wt \%) Washed & 0.0061 & 0.0055 & 0.0049 & 0.0045 & ASTM D 5453 \\
\hline $\operatorname{Gum}(\mathrm{mg} / 100 \mathrm{~mL})$ & 0.2000 & 0.2000 & 0.6000 & 0.2000 & ASTM D 381 \\
\hline Unwashed gum $(\mathrm{mg} / 100 \mathrm{~mL})$ & 18.8000 & 17.4000 & 15.0000 & 14.4000 & \\
\hline Lead content $(\mathrm{gL})$ & $<0.0025$ & $<0.0025$ & $<0.0025$ & $<0.0025$ & ASTM D 3237 \\
\hline Corrosivity $\left(3 \mathrm{~h}\right.$ at $\left.50^{\circ} \mathrm{C}\right)$ & la & la & la & la & ASTM D 130 \\
\hline Distillation temperature $\left({ }^{\circ} \mathrm{C}\right)$ & & & & & ASTM D 86 \\
\hline IBP & 35.5000 & 37.8000 & 36.7000 & 39.5000 & \\
\hline $10 \mathrm{vol} \%$ & 54.5000 & 50.8000 & 52.8000 & 54.8000 & \\
\hline $50 \mathrm{vol} \%$ & 94.4000 & 71.1000 & 70.3000 & 72.4000 & \\
\hline 90 vol\% & 167.3000 & 166.4000 & 163.0000 & 159.3000 & \\
\hline End point & 197.0000 & 197.5000 & 198.6000 & 198.3000 & \\
\hline Heating value ( $\mathrm{cal} \mathrm{g}^{-1}$ ) & 10176.0000 & 9511.0000 & 9316.0000 & 8680.0000 & \\
\hline Carbon (wt \%) & 86.6000 & 86.7000 & 87.6000 & 86.0000 & \\
\hline Hydrogen (wt $\%$ ) & 13.3000 & 13.2000 & 12.3000 & 13.9000 & \\
\hline Residue (vol\%) & 1.7000 & 1.5000 & 1.5000 & 1.5000 & \\
\hline Color & Yellow & Yellow & Yellow & Yellow & Visual \\
\hline
\end{tabular}

In addition to the regulated pollutants-Carbon Monoxide (CO), Hydrocarbons (HC), nitrogen oxides $\left(\mathrm{NO}_{\mathrm{x}}\right)$ and carbon dioxide $\left(\mathrm{CO}_{2}\right)$-emissions of benzene and methane from the gasoline cars) and toluene (from the diesel cars) were measured online by Chemical Ionisation Mass Spectrometry (CI-MS) (Saxer et al., 2003 for nonregulated emission measurements with warm engine).

Ethanol has advantages to prove its attraction. Table 1 shows the properties of ethanol and gasoline. It can be used as an additive or an alternative fuel for gasoline engines. With the addition of ethanol into gasoline, the fuel economy and thermal efficiency are improved and because of the high octane number, engines are allowed to operate under a higher compression ratio. Compared with gasoline, the lower boiling point, faster flame propagation speed, high oxygen content (50 wt \%) and simple chemical structure of methanol all help to reduce the $\mathrm{CO}$ and Hydrocarbon (HC) emissions, Hu et al. (2007). But $\mathrm{NO}_{\mathrm{x}}$ emissions do not always decrease; Liu et al. (2007) observed an increase by $5-10 \%$. However, the addition of methanol may cause a slight power loss, a cold start problem in deep cold conditions and the risk of a vapor block in hot weather. Power loss can be solved by prolonging the injection pulse width or by enlarging the injector's flow flux; the cold start and vapor block problems can be settled by providing particular methanol/gasoline blend fuels for summer and winter. Other disadvantages such as toxicity, separation from gasoline, erosion on plastic and rubber and so on can be solved by strictly sealing the fuel supply system, adding additives in fuel blends and changing to antierosion parts, respectively.
Jia et al. (2005) influence of ethanol-gasoline blended fuel on emission characteristics from a fourstroke motorcycle engine. The results indicate that $\mathrm{CO}$ and $\mathrm{HC}$ emissions in the engine exhaust are lower with the operation of E10 as compared to the use of unleaded gasoline, whereas the effect of ethanol on $\mathrm{NO}_{\mathrm{x}}$ emission is not significant. Furthermore, species of both unburned hydrocarbons and their ramifications were analyzed by the combination of Gas Chromatography/Mass Spectrometry (GC/MS) and Gas Chromatography/Flame Ionization Detection (GC/FID).

Al-Hasan (2007) study focuses on measurement of the engine exhaust emission and fuel consumption during engine warm-up period. In this study show that as the ambient temperature increases the concentration of both hydrocarbon and carbon monoxide and fuel consumption decreases while the carbon dioxide increases. Also, the time required for the engine to fully warm-up is shortened.

In previous studies, the Research Octane Number (RON) of the gasoline has been changed due to the addition of ethanol. The more ethanol added, the higher the RON; e.g., the RON values are 95, 98, 101, 102 and 105 for non-oxygenated unleaded gasoline, gasoline with 10, 20,30\% v/v ethanol blends and pure ethanol, respectively, Hsieh et al. (2002). Thus, the results previously obtained may not accurately represent the commercial gasoline in which the typical RON value ranges from 92-98. Octane number is also an impartment parameter for vehicle combustion. AlFarayedhi (2002) showed decreases in $\mathrm{CO}$ and $\mathrm{HC}$ emissions along with but higher NOx emission with increasing octane number of the fuel. The combustion duration becomes prolonged as octane number 
increases; longer combustion duration may result in low thermal efficiency and increased fuel consumption, Shen et al. (2008). Moreover, gasoline with a high octane number is suitable for vehicles with a high compression ratio. The compression ratios of motorcycles (8-10:1) are less than those for gasoline cars (9-12:1). High-ethanol content gasoline (>15\% $\mathrm{v} / \mathrm{v}$ ) may not be suitable for motorcycles due to its high octane number.

In this study, to investigate the effects of the ethanol/gasoline properties on Spark Ignition (SI) engine emission at warm-up process, especially unburned-Hydrocarbon emission, three typical methanol/gasoline blends of E0, E10, E20 and E30 were tested. An emission in the exhaust gas is measured by a portable gas analyzer Kane OIML CLAS 1 (N0356). The working principle of the tool is based absorbstivitas wave infrared radiation from the gas detection. Gas analyzer can detect $\mathrm{CO}_{2}, \mathrm{CO}, \mathrm{HC}$ and Air fuel ratio.

\section{MATERIALS AND METHODS}

Experiment will be done at port-injection gasoline engines four cylinders connected by eddy current dynamometer, as shown at Fig. 1. Engine data is shown in the Table 2 . In this experiment done on the unload engine, or it can be called free running. From experiment will be found is an rpm engine, exhaust emissions and fuel consumption.

Table 2 Engine specification

\begin{tabular}{lr}
\hline Engine parameter & \multicolumn{1}{c}{ Value } \\
\hline Bore $(\mathrm{mm})$ & 81.000 \\
Stroke $(\mathrm{mm})$ & 77.500 \\
Displacement $\left(\mathrm{cm}^{3}\right)$ & 1.597 \\
Number of cylinder & 4.000 \\
Connecting rod length $(\mathrm{mm})$ & 118.100 \\
Max. intake valve open $(\mathrm{mm})$ & 7.095 \\
Max. exh. valve open $(\mathrm{mm})$ & 7.095 \\
Intake valve open & 140.000 \\
Close & 580.000 \\
Exhaust valve open & 520.000 \\
Close & 160.000 \\
\hline
\end{tabular}

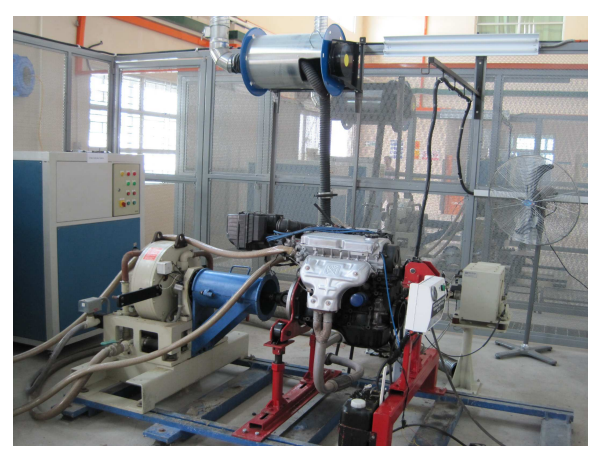

Fig. 1: Engine and dynamometer
Fuel consumption is measured using a measuring cup with a volume of $100 \mathrm{~mL}$, duration of fuel use in measuring with a stop watch. An emission in the exhaust gas is measured by a portable gas analyzer Kane OIML CLAS 1 (N0356). The working principle of the tool is based absorbstivitas wave infrared radiation from the gas detection. Gas analyzer can detect $\mathrm{CO}_{2}, \mathrm{CO}, \mathrm{HC}$ and Air fuel ratio.

Exhaust gas emissions, engine speed and fuel consumption collect at forth time condition, in the 5, 10, 15 and the last is $20 \mathrm{~min}$ after engine start. Fuel used is petroleum for comparison and also different Ethanol/petroleum blend E 10, E20 and E30. To get the same environmental conditions, testing is done in the morning. This is also done to ensure the condition of engine cold conditions.

\section{RESULTS AND DISCUSSION}

Influence of emission: Ethanol addition greatly influences fuel properties, such as shown in Table 1. Ethanol causes fuel experiencing significant changes, such as changes in octane number, density, heating value and also the oxygen content. Fuel properties Changes influenced in the burning process. In this study will be discussed about addition effect of ethanol in gasoline fuels on the emissions that occur during warm-ups.

Oxygen content in the ethanol caused improves combustion process. Yung et al. (2009) shows oxygen contain ethanol will cause air-fuel ratio to be increased. But in this study showed different results, ethanol addition in the fuel causes the fuel mixture becomes richer. This can be seen in Fig. 5. Where for $300 \mathrm{sec}$ up to $600 \mathrm{sec}$, running engine use ethanol fuel make reduce air-fuel ratio, this condition shown if fuel mixture become richer. But with increasing time, fuel composition changes become lean. Results of experiments conducted with 300-600 sec early show a very significant change. At $300 \mathrm{sec}$ from the start, the addition of ethanol in the fuel causes the combustion process produces many un-burned hydrocarbons and carbon dioxide.

Higher concentration of ethanol in the fuel causes un-burn hydrocarbon increases. With increasing time for warm-up, un-burn hydrocarbon decreased (Fig. 3). In this study, when engine uses gasoline fuel produce $315 \mathrm{ppm}$ HC At the $300 \mathrm{sec}$ warm-up and $243 \mathrm{ppm}$ at $1200 \mathrm{sec}$. Addition of $10 \%$ ethanol will produce 364 ppm $\mathrm{HC}$ at $300 \mathrm{sec}$ and $330 \mathrm{ppm}$ for $1200 \mathrm{sec}$, while $30 \%$ addition of ethanol in fuel has produce $391 \mathrm{ppm}$ $\mathrm{HC}$ at $300 \mathrm{sec}$ and $120 \mathrm{ppm}$ at $1200 \mathrm{sec}$. HC will be more produced by getting additional fuel ethanol compared with gasoline fuel for the early start, but after $300 \mathrm{sec}$ warm-up process of the addition of ethanol will produce smaller HC. 
At the start use ethanol fuel requires more fuel compared gasoline. This show in Fig. 5, addition of ethanol in the fuel causes the air-fuel ratio is lower. Amount of fuel in the combustion chamber at engine start resulted in a lot of fuel can't burned completely. Higher amount of un-burn fuel can increase $\mathrm{HC}$ and CO produced in the combustion process. Apart from the number of fuel can not burn completely, $\mathrm{HC}$ at the start to be more in the causes of the condition of the engine is still cold. The condition of the engine is still cool cause oil film that coats the piston and cylinder wall is high. These conditions resulted in front flame much oil trapped in the film thereby increasing the formation of un-burned hydrocarbons.

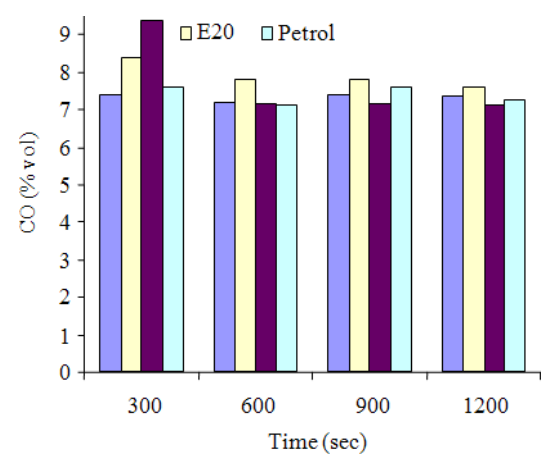

Fig. 2: $\mathrm{CO}$ emission from different time warm-up

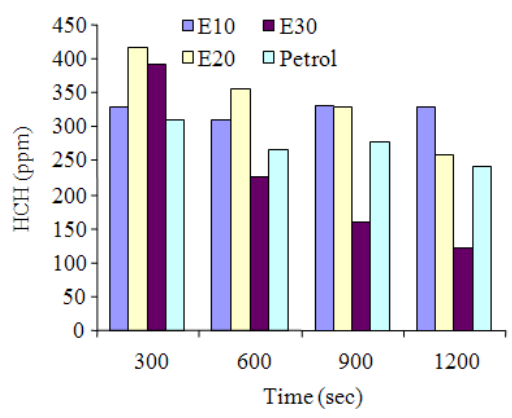

Fig. 3: Hydrocarbon at warm-up

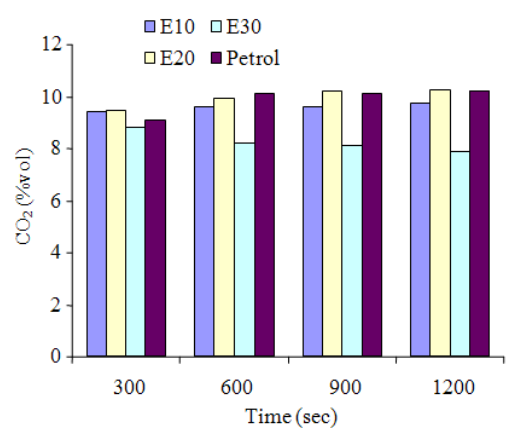

Fig. 4: $\mathrm{CO}_{2}$ at different time warm-up
Besides influence in the $\mathrm{HC}$, ethanol addition also affects on $\mathrm{CO}$ produced. In this study, ethanol/gasoline blend produce higher $\mathrm{CO}$, in Fig. 2 show, at $300 \mathrm{sec}$ the highest $\mathrm{CO}$ emissions produced by the ethanol/gasoline $30 \%$. After $600 \mathrm{sec}$ of warm-up, increasing concentration of ethanol in the fuel will be reduce $\mathrm{CO}$ produced.

Increasing $\mathrm{CO}$ in combustion production at the warm-up shows incomplete combustion process, this is strengthened by the combustion temperature is lower (Fig. 4).

Effect of fuel properties on combustion temperature: Fuels with low heating value lower will result in a low temperature combustion process. This can be seen in Fig. 7 which shows the effect of changes in fuel properties on the lubricating oil temperature. The addition of $10 \%$ ethanol has a lubricating oil temperature highest during 300 and $600 \mathrm{sec}$ the engine at the start. After $900 \mathrm{sec}$, the highest temperature occurred on gasoline fuel. Generally, the higher concentration of ethanol in fuel, oil temperature will be lower.

The amount of fuel into the combustion chamber also affects the combustion temperature. The use of ethanol in fuel will increase the amount of fuel into the combustion chamber; this is the show in Fig. 6 .

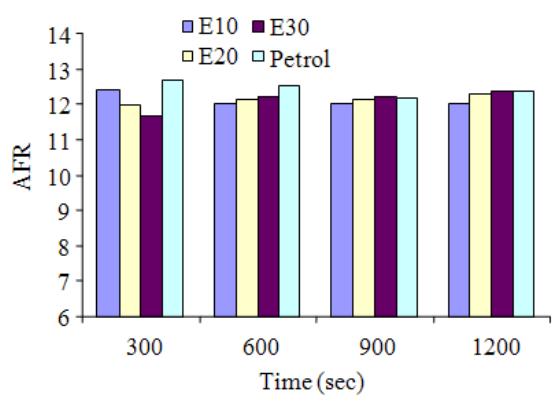

Fig. 5: Air-fuel ratio

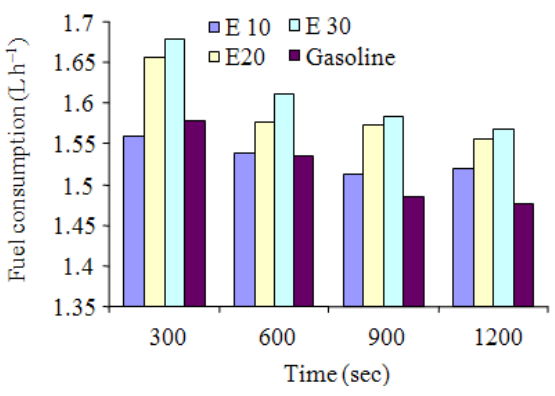

Fig. 6: Fuel consumption 


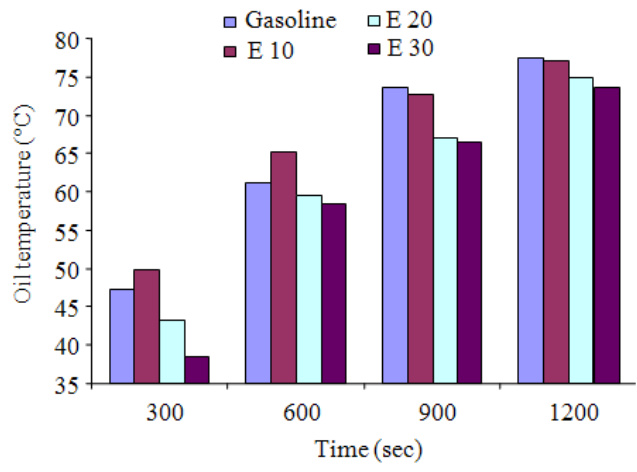

Fig. 7: Oil temperature

At start of $30 \%$ ethanol has higher fuel consumption. Too much fuel in the combustion chamber will cause the combustion process is less than perfect. With the number of un-burnt fuel, energy is released in combustion will also be reduced.

\section{CONCLUSION}

Results from this study indicate that fuel properties have been affects to engine emission during warm-ups. With ethanol addition in the fuel increased fuel consumption and air-fuel ratio is getting rich and reduce combustion temperature. Ethanol addition at the start will generate higher emissions, both $\mathrm{CO}$ and $\mathrm{HC}$. But with increasing operation time, ethanol addition will be reducing emissions.

\section{REFERENCES}

Al-Farayedhi, A.A., 2002. Effects of octane number on exhaust emissions of a spark ignition engine. Int. J. Energy Res., 26: 279-89. DOI: 10.1002/er.783
Al-Hasan, M., 2007. Evaluation of fuel consumption and exhaust emissions during engine warm-up. Am. J. Applied Sci., 4: 106-111. DOI: 10.3844/ajassp.2007.106.111

Hsieh, W.D., R.H. Chen, T.L. Wu and T.H. Lin, 2002. Engine performance and pollutant emission of an SI engine using ethanol-gasoline blended fuels. Atmos. Environ., 36: 403-410. DOI: 10.1016/S1352-2310(01)00508-8

Hu, T., Y. Wei, S. Liu and L. Zhou, 2007. Improvement of Spark-Ignition (SI) engine combustion and emission during cold start, fueled with methanol/gasoline blends. Energy Fuels, 21: 171-175. DOI: 10.1021/ef0603479

Jia, L.W., M.Q. Shen, J. Wang and M.Q. Lin, 2005. Influence of ethanol-gasoline blended fuel on emission characteristics from a four-stroke motorcycle engine. J. Hazardous Mater., 123: 29-34. DOI: 10.1016/j.jhazmat.2005.03.046

Liu, S., E.R.C. Clemente, T. Hu and Y. Wei, 2007. Study of spark ignition engine fueled with methanol/gasoline fuel blends. Applied Therm. Eng., $\quad 27$ : 1904-1910. DOI: 10.1016/j.applthermaleng.2006.12.024

Saxer, C.J., A.M. Forss, M. W. and N.V. Heeb, 2003. Benzene emission factors of the latest diesel-and gasolinefuelled passenger cars within the common artemis driving cycle. Avignon France, 2: 153-159.

Shen, Y., S. Shuai, J. Wang and J. Xiao, 2008. Effects of gasoline fuel properties on engine performance. SAE International. DOI: 10.4271/2008-01-0628

Yung, Y.C., J.H. Tsai and H.L. Chiang, 2009. Effects of ethanol-blended gasoline on air pollutant emissions from motorcycle. Sci. Total Envoirn., 407: 5257-5262. DOI: 10.1016/j.scitotenv.2009.06.017 